\title{
DE INTERNE CONTROLE BIJ DE \\ REKENING-COURANTVERWERKING VAN ALGEMENE BANKEN
}

door Drs. P. A. van Genderen

\section{Inleiding}

Het is de bedoeling in dit artikel na te gaan hoe de interne controle bij de dagelijkse rekening-courantverwerking van algemene banken haar beslag zal moeten krijgen respectievelijk heeft gekregen bij nogal ingrijpende veranderingen in de verwerkingssystematiek. In de bespreking zullen drie duidelijk te onderkennen ontwikkelingsfasen in de administratieve organisatie en -techniek aan de orde komen.

Deze drie fasen zijn:

1 de paralleladministratie

2 de single run methode, met hoofdzakelijk centrale imputering

3 de recente ontwikelingen naar veelal gedecentraliseerde of externe vastlegging van basisgegevens

Onderzocht zal worden welke extra of aangepaste maatregelen van interne controle nodig zijn om te verzekeren, dat bij overgang op een andere verwerkingsmethode toch eenzelfde hoge graad van betrouwbaarheid gehandhaafd blijft ten aanzien van het eindresultaat.

Is de paralleladministratie reeds geruime tijd bekend, de single run methode is voor de grotere banken in Nederland van vrij recente datum, terwijl de ontwikkelingen naar enerzijds interne, decentrale, op terminals gebaseerde informatieverzameling, en anderzijds naar buiten de individuele bank ontstane vastleggingen, een tijdperk markeren dat nog maar nauwelijks is begonnen. Aan de nieuwe, nog niet geconsolideerde, ontwikkelingen zal meer aandacht worden besteed dan aan de uitgebalanceerde paralleladministratie.

\section{De rekening-courantadministratie}

De rekening-courantadministratie is de afdeling die zorg draagt voor de administratie van de rekeningen die bij een bank worden aangehouden. Daarbij gaat het uiteraard in eerste aanleg om door derden (cliënten) aan de bank toevertrouwde gelden of door de bank verstrekte geldmiddelen. Daarnaast worden door de rekening-courantafdeling geadministreerd de rekeningen die door de bank voor eigen gebruik zijn geopend, zoals tussenrekeningen en schaduwrekeningen (spiegelbeeld van bij andere banken aangehouden rekeningen bekend onder de naam nostrorekeningen).

De administratie zoals die door de rekening-courantafdeling wordt gevoerd omvat de volgende elementen:

1 Het verschaffen van een nauwkeurig overzicht van het verloop van de rekeningen, d.w.z. aantekening te houden wanneer, op grond waarvan en tot welke bedragen de cliënten vorderingen op de bank dan wel schulden aan de bank hebben gekregen.

2 Het bepalen hoe hoog het saldo van elke rekening is. Dat is nodig, omdat telkens wanneer een rekeninghouder een opdracht geeft terzake waarvan 
zijn rekening moet worden belast, de positie-fiatteur zich er van moet overtuigen dat het saldo toereikend is respectievelijk passend is in het kredietarrangement. Dit onderdeel van de rekening-courantadministratie staat veelal bekend onder de naam positie-administratie.

3 Het verstrekken van informatie aan de cliënten. Voor de meeste soorten rekeningen zijn dagafschriften gebruikelijk; het komt evenwel ook voor dat slechts maand- of kwartaalafschriften worden verstrekt. Dit is voornamelijk afhankelijk van de mutatiegraad van de rekening.

4 Het verzamelen respectievelijk bewaren van gegevens die nodig zijn om periodiek intrest, provisie of kosten te kunnen berekenen, en ten gunste of ten laste van de rekening te boeken.

5 Het verzamelen van gegevens die van belang zijn om de relatie met een cliënt op haar financiële mérites te kunnen beoordelen. Deze beoordeling staat bekend als account profitability. $\mathrm{Zij}$ kan aanleiding geven tot herziening van de voorwaarden waaronder een rekening wordt gevoerd. Bovendien kan zij van groot belang zijn voor de bepaling van de richting waarin een bank haar acquisitie activiteiten moet uitstrekken.

6 Het verzamelen van gegevens die van belang zijn in het kader van de zgn. reciprociteitsbeoordeling. Daaronder verstaat men de beoordeling of het verkeer met een buitenlandse bank (correspondent genaamd) al of niet remuneratief is.

De interne controle in het algemeen

Waarom is de interne controle bij banken zo belangrijk?

Bij banken gaat het voornamelijk om geld. En geld is zo'n aanlokkelijk, universeel aanwendbaar en vaak niet-identificeerbaar behoeftebevredigingsmiddel, dat een uiterst solide bewaking geboden is van ,de voorraad" - in chartale of girale vorm, maar in ieder geval geld van derden - alsmede van de mutaties in de voorraad. Tegen twee omstandigheden in het bijzonder moet worden gewaakt:

1 Overtrekking van het tegoed respectievelijk het toegestane krediet op een rekening.

1.1 De preventieve controle gedurende de dagelijkse operaties ligt bij de positie-fiatteur, althans voorzover de opdracht hem onder ogen is geweest respectievelijk met zijn medeweten ten uitvoer is gebracht. Dit voorbehoud wordt met opzet gemaakt, omdat een toenemend aantal debiteringen buiten zijn vóórkennis wordt verricht. Het meest sprekende voorbeeld hiervan is de nog steeds groeiende stroom betaalcheques, waaraan de door de uitgevende bankinstellingen gegeven bedraggarantie van hoger orde is dan het feit of de trekker voldoende saldo op zijn rekeing heeft. Ook moet de ontwikkeling worden genoemd van betalingsvormen, waarbij het initiatief tot de betaling genomen wordt door de crediteur, zoals de verschillende varianten van bankincasso, die steeds meer worden toegepast.

1.2 Bij de controle achteraf, d.w.z. na de veelal dagelijkse bijwerking van de rekeningen, vervult de rekening-courantadministratie een belangrijke rol

$m a b$ blz. 58 
doordat zij aan de bedrijfsleiding signaleert bij welke rekeningen disponeringen tot grotere totalen dan toegestaan hebben plaatsgevonden. (exception rule)

1.3 De controle achteraf zou niet nodig zijn indien de positie-fiatteur de beschikking zou hebben over continu bijgewerkte saldi. Dat is slechts te bereiken bij een volledige, d.w.z. een alle bankafdelingen rakende, real-time bijwerking met behulp van een computer, een stand van zaken die nog bij geen enkele bank bestaat. Het is niet waarschijnlijk dat een dergelijke situatie zal ontstaan, en wel om de volgende redenen:

In de eerste plaats bestaat er geen dringende behoefte aan deze faciliteit omdat de fouten gemaakt bij het beoordelen van het actuele saldo qua aantal en qua nadelige gevolgen in het niet vallen bij andere beoordelingsfouten, b.v. die uit kredietverlening met een ongefundeerd optimistische visie op het winstperspectief van een onderneming.

In de tweede plaats speelt een rol dat een fiatteur niet alle mutaties even grondig zal behoeven te fiatteren omdat hij de cliënt en de geldbewegingen op de rekening kent. Hierin schuilt overigens wel het gevaar dat hij juist bij deze categorie te goeder naam en faam bekend staande cliënten te lichtvaardig te werk gaat.

Ten derde moet worden verwacht dat real-time saldobijwerking zeer aanzienlijke kosten met zich zal meebrengen daar alle mutaties direct bij hun ontstaan postgewijs moeten worden verwerkt.

2 Onopzettelijke of frauduleuze handelingen die de stand van een rekening beïnvloeden.

2.1 Fouten en vergissingen benadelen het image van de bank als een instelling die het nauw neemt met de zorgvuldigheid van de registratie van de haar toevertrouwde zaken. Een fout van enige importantie haalt tenminste de veelgelezen pagina's van de dagbladen.

2.2 Frauduleuze handelingen kunnen de bank veel geld kosten en dragen indien zij in de publiciteit komen - evenmin bij tot het beeld van betrouwbaarheid en bestendigheid (ook tegen bedrog) waarvan elke bank een toonbeeld wil zijn.

Het is goed onderscheid te maken waar de basis van de bedrieglijke handeling ligt, binnen de bank of buiten de bank.

- Onrechtmatigheden die geïnitieerd worden door derden, moeten onderkend worden voordat de bank tot uitvoering van een opdracht overgaat. Meestal gaat het hierbij om kwesties omtrent beschikkingsbevoegdheid over aangehouden tegoeden of verstrekte kredietfaciliteiten.

- Ook aan malversaties die binnen de bank hun oorsprong hebben, d.w.z. in de persoon van een bankemployé, zal het hoofd geboden moeten worden. In beginsel zijn er twee vormen van fraudemogelijkheden:

- het ten eigen bate „ombuigen" van opdrachten bestemd voor cliënten van de bank of andere begunstigden.

- het ten eigen bate aanwenden van de tegoeden van cliënten (met name zgn. slapende rekeningen) of rekeningen in beheer bij de bank zelf (b.v. tussenrekeningen voor de stalling van nog niet aan derden verantwoorde gelden). 
Een belangrijk aspect met betrekking tot het belang van een doeltreffende interne controle is gelegen in het feit dat het initiatief voor het merendeel van de transacties niet door de bank genomen wordt, doch veelal van derden, d.w.z. cliënten, uitgaat. Een goede cliëntenservice verlangt dat bij ontvangst van een opdracht geen vertraging ontstaat, b.v. omdat de bankadministratie nog bijgewerkt zou moeten worden. Een dergelijke vertraging is onaanvaardbaar. Dit uitgangspunt voor het handelen van een bank betekent daarom dat de gegevens op grond waarvan tot de uitvoering van een opdracht wordt overgegaan, absoluut in orde moeten zijn. Maatregelen van interne controle zullen deze situatie moeten veiligstellen.

\section{Waarop moet controle worden uitgeoefend?}

Bij de verwerking van gegevens in de rekening-courantadministratie kunnen duidelijk een aantal punten worden aangewezen, waarover zekerheid moet bestaan, voordat gesteld kan worden dat de transacties correct zijn geboekt. Deze controlepunten hebben algemene geldingskracht, in die zin dat zij moeten worden gehonoreerd, ongeacht de verwerkingssystematiek die door een bank wordt gekozen.

De systeemonafhankelijke controle moet gericht zijn op het verkrijgen van zekerheid

1 dat de boeking geinitieerd is door een daartoe bevoegd functionaris

2 dat op de juiste rekening is geboekt

- juiste rekeninghouder

- juiste rekeningsoort

- juiste muntsoort

3 dat het juiste bedrag is geboekt

- in de juiste muntsoort

- met de juiste transactieaanduiding

- aan de juiste zijde van de rekening (debet/credit)

4 dat aan de boeking de correcte valutering is toegekend

5 dat het saldo juist is berekend, d.w.z. dat uitgegaan wordt van een juist "oud" saldo en de mutaties op zodanige wijze worden verwerkt dat een juist ,,nieuw" saldo ontstaat

6 dat alle bedragen zijn geboekt, d.w.z. dat de volledigheid van het boekingsmateriaal wordt vastgesteld. Dit omvat anderzijds tevens de controle op een surplus aan niet-geautoriseerde boekingen. De controle beperkt zich niet alleen tot de initiële vastleggingen, maar strekt zich vanzelffsprekend evenzeer uit tot de correcties van posten die niet op normale wijze in boekingen konden worden omgezet.

\section{De interne controle bij de paralleladministratie}

Waarom paralleladministratie?

In de tijd dat slechts de ",happy few" bankcliënt konden worden, en het aantal mutaties per rekening gering was, bestond voor elk bankkantoor de mogelijkheid om de voor de zeer gewaardeerde cliënt vervaardigde, soms

ma $b$ blz. 60 
handgeschreven nota's en rekeningafschriften, die niet zozeer dagelijks, maar maandelijks of eenmaal per kwartaal werden verstrekt, grondig te controleren met de brondocumenten die tot wijziging van het rekeningsaldo aanleiding gaven, alvorens de stukken aan de cliënt te verzenden of bij hem thuis te bezorgen. Ten gevolge van de versnelde groei van het aantal bankcliënten, gepaard gaande met een popularisering van het girale betalingsverkeer, kon een dergelijke individuele behandeling niet meer worden voortgezet.

Toch wilden de banken waarborgen scheppen, dat fouten tot een minimum beperkt zouden blijven. Zekerheid dat het totaal geboekte bedrag in overeenstemming was met de som van de notabedragen vormde geen probleem. De aansluiting was op simpele wijze te verkrijgen. Minder eenvoudig was het verschaffen van zekerheid dat het juiste bedrag op de juiste rekening werd geboekt. Immers, bij een sluitende totaalcontrole kunnen toch, elkaar opheffende, fouten plaatsvinden. De banken vonden een oplossing voor dit probleem door de rekening-courantadministratie dubbel uit te voeren. Deze werkwijze staat in het algemeen bekend als de paralleladministratie of dual c.q. double run.

\section{Wat is paralleladministratie?}

Er wordt weleens gedacht, dat de paralleladministratie betekent, dat alle werkzaamheden zondermeer tweemaal op identieke wijze worden uitgevoerd. Dat is een onjuiste gedachte. Geheel los van het feit welke technische hulpmiddelen werden gebruikt, vertoonde zich in het algemeen het volgende beeld:

1 De traditionele rekening-courantadministratie, uitmondend in de berichtgeving aan de cliënt, werd zonder veel wijziging voortgezet.

2 De administratieve handelingen die toch al werden gedaan om de hoofdboekhouding (het grootboek) bij te werken, werden dienstbaar gemaakt aan de controle op de rekening-courantadministratie. Daartoe werden in deze paralleladministratie ook de saldi en mutaties op de personenrekeningen geregistreerd.

Kenmerk van deze wijze van werken was, dat beide administraties met behulp van ( 2 verschillende) doorslagen van de voor de cliënt vervaardigde nota's werden bijgewerkt.

Of de notagegevens klopten met de gegevens op het brondocument waarop de opdracht was gesteld, is een andere vraag. De controle hierop behoorde tot de verantwoordelijkheid van de bankafdeling die de conversie verzorgde. Degene op de bedrijfsafdeling die de originele nota's ter controle kreeg voorgelegd, d.i. de afdelingschef of bij delegatie een andere afdelingsfunctionaris, parafeerde bij accoordbevinding op de boekingscopieën en tekende veelal de originele nota. Ook op het brondocument werd aangetekend dat de nota conform de opdracht was gemaakt. Duidelijk is dat het de controlefunctionaris niet toegestaan is zelf nota's gereed te maken.

Het spreekt vanzelf, dat naarmate het bancaire verkeer in omvang toenam, de banken er naar streefden de conversie van brondocumenten zoveel mogelijk te voorkomen. $\mathrm{Zij}$ bereikten die situatie door de cliënt formulieren in meervoud ter beschikking te stellen, waarvan na verwerking door de bank 
een gesigneerde doorslag bij het rekening-uittreksel van de cliënt werd gevoegd. Duidelijk voorbeeld hiervan vormen de betalingsopdrachtformulieren (bankgiro's), nog steeds het meest gebruikte formulier in het betalingsverkeer, die aan de cliënten sedert 1961 ten gebruike worden gegeven.

\section{Hoe word t bij de paralleladministratie de interne controle gerealiseerd?}

Voorop gesteld moet worden dat de interne controle onder de paralleladministratie grotendeels wordt verwezenlijkt door de aard van de verwerkingsmethode zelve. Daarmede wordt bedoeld, dat het juist overwegingen van interne controle zijn geweest, die banken aanleiding hebben gegeven om de paralleladministratie te gaan toepassen.

De tweede registratie biedt voldoende zekerheid op de juistheid in het traject dat ligt tussen het verwerken van de boekingsstukken en de productie van de nieuwe saldi van de rekeningen, omdat:

- Twee vastleggingen plaatsvinden, waarvan de resultaten zowel per rekening als in totaal met elkaar worden vergeleken.

- Zeker wanneer tevens nog wordt nagegaan of de gegevens van de separaat ter verzending verstrekte originelen van de boekingsdocumenten inderdaad op het gelijknamige dagafschrift zijn terug te vinden.

Controlemaatregel van grote belangrijkheid is de toezending aan de cliënt van een rekeningafschrift, bij voorkeur op de dag waarop een mutatie plaatsvindt. Er moet uiteraard voor worden zorg gedragen, dat klachten inzake rekeningafschriften behandeld worden door anderen dan personeelsleden van de sectie van de rekening-courantafdeling, die de boekingen hebben verzorgd.

Een controlemaatregel die, hoewel van veel geringer importantie, niet onbesproken mag blijven, is de toezending van saldobiljetten, hetgeen gewoonlijk eenmaal per jaar plaatsvindt. Vooral voor rekeningen die weinig muteren kan inroeping van de hulp van de cliënt bij de controle op het rekeningsaldo nuttig zijn, ofschoon van tijdige maatregelen ingeval van onregelmatigheden niet meer kan worden gesproken.

\section{De interne controle bij de single run methode}

\section{Waarom single run?}

"Niettemin" schrijft prof. Starreveld, ,heeft men in de praktijk hier en daar het systeem van dubbele administratie verlaten”. Dat „niettemin” heeft betrekking op de in zijn ogen adequate controletechnische zekerheden waarin de paralleladministratie voorziet. Het zijn dus duidelijk niet, zoals destijds bij de overgang naar de paralleladministratie, overwegingen van interne controle geweest, die de banken naar het zgn. single run systeem deden overstappen. Welke redenen dan wel?

Het is een combinatie van drie factoren geweest, die in de jaren zestig de single run verwerking deden ontstaan, n.l.:

1 De zeer grote aantallen posten die dagelijks (dubbel) moesten worden verwerkt. Het einde van de snelle groei was nog niet in zicht, integendeel.

2 De door de verkeersomvang eveneens sterk groeiende vraag naar moeilijk

$m a b$ blz. 62 
te krijgen parttime personeel in een tijdperk van explosief stijgende salarissen. (Parttimers, omdat de rekening-courantverwerking eigenlijk eerst goed op gang kon komen als de bedrijfsafdelingen een zo groot mogelijk gedeelte van hun dagproductie hadden behandeld).

3 De mogelijkheden van tweede en derde generatie computers, die door hun grote geheugencapaciteit, de hoge interne verwerkingssnelheid en de snelle afdrukmogelijkheden, een betere keuze leken dan conventionele apparatuur bediend door steeds duurder wordend personeel.

Wat is single run?

$\mathrm{Bij}$ single run verwerking gaat het om vastlegging van de boekingsposten in enkelvoudige vorm, het successievelijk verwerken van de in machinaal leesbare vorm vastgelegde gegevens en het afdrukken door de computer van dagafschriften en andere bescheiden. Dat is de kern van de single run verwerking. Van dubbel uitvoeren is geen spoor meer te vinden.

Invoering van de single run methode heeft op de organisatie van de rekening-courantafdeling grote invloed gehad, in die zin, dat de personeelsbezetting sterk is verminderd. De reden ligt voor de hand, n.l. het wegvallen van een boekingsgang. Er zijn, zoals nog zal blijken hier en daar enkele nieuwe taken ontstaan, in het bijzonder bij de inputvoorbereiding en de controle op de computerverwerking. Per saldo heeft de overgang naar de single run verwerking de banken toch een aanzienlijke besparing op personeelskosten opgeleverd.

\section{De introductie van het beveiligde rekeningnummer}

Tegen het einde van de jaren vijftig en in het begin van het afgelopen decennium gingen de banken terrein verliezen aan de hooggeautomatiseerde Postcheque- en Girodienst. Het verlies manifesteerde zich in een dalend aandeel van de banken in de girale geldhoeveelheid. Deze ontwikkeling dwong de banken tot bezinning, welke leidde tot de conclusie dat, wilden de banken voldoende greep op het creditgeldenreservoir houden, bundeling van krachten op het terrein van de dienstverlening bij het betalingsverkeer dringend nodig was.

De ten opzichte van de postgiro te lang geworden behandelingsduur van een bankopdracht vormde een belemmering voor de verdere groei van de banken, juist in een periode dat veel potentiële bankcliënten bereikbaar werden door de snelle invoering van girale salarisbetalingen.

De tegenzet van de banken kreeg gestalte in de Bankgirocentrale, die vanaf eind 1967 haar diensten als centraal clearing- en computerverwerkingscentrum aan de gezamenlijke banken ging verlenen. Op de functie van de Bankgirocentrale wordt in het volgende hoofdstuk nader terug gekomen.

Voorwaarde voor een goed functionerend geautomatiseerd betalingsverkeer was, dat alle daarvoor in aanmerking komende bankrekeningen een uniek rekeningnummer zouden krijgen. De gezamenlijke banken besloten daartoe in 1965, en schaften de tot dat jaar door elke bank zelfstandig toegekende rekeningnummers af.

Gekozen werd voor een bankrekeningnummer van 10 cijfers, waarvan de 
laatste positie een controlecijfer is, beter bekend onder de naam check digit (de eerste positie wordt als reserve beschouwd en vooralsnog op 0 ge initialiseerd).

Duidelijk is, dat de introductie van een beveiligd rekeningnummer ten behoeve van de versnelling van het betalingsverkeer, van grote betekenis is geweest voor de administratieve verwerking binnen de banken zelf. Het zich zelf controlerende rekeningnummer is n.l. een belangrijk controlemiddel wanneer bij de verwerking een computer is ingeschakeld of door middel van andere apparatuur een opgegeven rekeningnummer kan worden nagerekend (check digit verifiers). De 9-cijferige bankrekeningnummers vormen als zodanig dus een niet meer weg te denken onderdeel van het gehele pakket van controlemaatregelen.

Hoe wordt de interne controle onder het single run systeem verwezenlijkt? Single run betekende een heropening van de gesprekken en gedachten over de vormgeving van maatregelen van interne controle. Veel inventiviteit was nodig om juist die controlemaatregelen te bedenken, die ook op de langere duur effectief zouden zijn, en anderzijds het streven naar doelmatigheid waarvan de single run gedachte exponent was, niet doorkruisten.

Het is daarom waarschijnlijk, dat een groot deel van de tijd die besteed is aan de ontwikkeling van de systeemconceptie, heengegaan is aan het doorvorsen en doorspreken van vele hypothetische gevallen van vergissingen en onregelmatigheden die zich onder het single run systeem zouden kunnen voordoen. Niet uit het oog verloren mag worden, dat de single run methode, na zovele jaren van paralleladministratie een revolutionaire ontwikkeling is, en dàt binnen een bedrijfstak die behoudendheid (in de goede zin van het woord) van oudsher in haar vaandel heeft geschreven. Het aanvaarden van de single run methode betekende een ingrijpende verandering, ook in mentaal opzicht, die vele manjaren studie en voorbereiding vergde, en in de implementatiefase veel begeleiding vereiste.

$\mathrm{Bij}$ de bespreking van de maatregelen van interne controle is het goed onderscheid te maken tussen een tweetal verschillende benaderingen, t.w. de uitvoering die naast controle op de invoer van gegevens ook de output in de vorm van dagafschriften in de controle opneemt en anderzijds de aanpak die een zodanig zware controle op de input legt, dat de papieren output niet meer gecontroleerd wordt.

In het vervolg zal de eerste benadering output-georiënteerd worden genoemd en bij de tweede oplossing gesproken worden over input-georiënteerd.

\section{De output-georiënteerde controle}

Met dit systeem wordt bedoeld een werkwijze, die van de gedachtengang uitgaat, dat het een goede zaak is computer-output aan een visuele controle te onderwerpen, ook al zijn er uitgebreide maatregelen genomen voor het verkrijgen van een feilloze output. Het is niet zo, laat dat meteen gezegd worden, dat de inputhandelingen en de computerverwerking zonder enige controle plaatsvinden. Integendeel. Wel is een feit dat de controle, in het bijzonder op de vastlegging in machinaal leesbare vorm van de boekingsgege- 
vens, niet per se $100 \%$ behoeft te zijn omdat er altijd nog een nacontrole plaatsvindt.

De genoemde visuele controle houdt in dat geverifieerd wordt of:

1 Rekeningnummer en naam van enerzijds nota en anderzijds dagafschrift overeenstemmen, en

2 Of het juiste bedrag is geboekt.

Direct moet opgemerkt worden, dat de tweede controle oppervlakkiger kan zijn dan de eerste, omdat bij de invoervastlegging en bij de computerverwerking reeds maatregelen zijn genomen die beogen de volledigheid van het boekingsmateriaal vast te stellen. Ook behoeft geen vrees te bestaan dat een foutief nummer als zodanig is gebruikt. Ook dat zou al in een eerder stadium zijn gesignaleerd. Waar het om draait is of naam en rekeningnummer bij elkaar horen.

De visuele vergelijking tussen de originele nota's en dagafschriften heeft voordelen. In de eerste plaats wordt bereikt dat wordt gecontroleerd of op de juiste rekening van de juiste cliënt is geboekt. Ten tweede wordt vastgesteld of er van iedere post op het dagafschrift een specificatie in de vorm van een nota is. Dat is voor de cliënt een belangrijke zaak, omdat hij anders onvolledig ingelicht wordt. Bij toezending van alleen een nota kan hij zich afvragen waar zijn dagafschrift blijft; bij ontvangst van een dagafschrift zonder specificatie kan hij zich afvragen waarop de boeking betrekking heeft. In beide gevallen wordt de cliënt in het ongewisse gelaten en kan een telefonische of schriftelijke vraag om inlich tingen worden verwacht.

Nadeel van de methode is, dat het een bewerkelijke zaak is om zovele stukken visueel te vergelijken, en dàt juist in een tijdperiode dat meestal haast geboden is om het laatste postaanleveringstijdstip te halen. Ook kan van visuele controle niet worden gezegd, dat volledige zekerheid wordt verkregen.

\section{De input-georiënteerde controle}

Verschil met de zojuist besproken werkwijze is, dat bij de input-georiënteerde controle er van wordt uitgegaan dat de gedurende het verwerkingsproces toegepaste controles een visuele nacontrole van de geproduceerde dagafschriften overbodig maken. Daarom wordt de inputverzorging extra bewaakt en wel door middel van het gebruik van controlegetallen, waarnaar ook prof. Starreveld verwijst, wanneer hij de overgang naar de single run methode onder de loep neemt.

De extra beveiliging is gericht op het boeken op de juiste rekening van de juiste cliënt. De gang van zaken daarbij is als volgt. Aan elk rekeningnummer wordt een twee- of driecijferig controlegetal toegekend, zodanig dat een maximale spreiding van de getallen over het rekeningenbestand wordt bereikt.

$\mathrm{Bij}$ voorkeur wordt het controlegetal gevormd door een rekenregel toe te passen op het 9-cijferige bankrekeningnummer. Daardoor wordt mogelijk gemakt dat een controlegetal bij de acceptatie van de invoer machinal kan worden nagerekend. Er wordt dus in feite eenzelfde situatie geschapen als bij het beveiligde bankrekeningnummer. 
De bedoeling is nu, dat elke nota die ter boeking wordt aangeboden, wordt voorzien van een controlegetal door een andere functionaris dan de maker van de nota. Op de nota worden naam en rekeningnummer ingetypt, alsmede een aanduiding van de rekeningsoort, op een notacopie wordt het controlegetal bijgeschreven, opgezocht met behulp van registers waarin alleen namen, rekeningsoorten en controlegetallen voorkomen. De aldus langs twee wegen ontstane combinatie rekeningnummer-controlegetal (eigenlijk een stukje paralleladministratie) wordt in een machinaal leesbare informatiedrager, veelal papieren ponsband of optisch leesbare stroken, vastgelegd en door een computerprogramma ingelezen. Het programma rekent na of het 9-cijferig nummer aan de 11 proef voldoet (dat kan overigens ook al door een check digit verifier gekoppeld aan de conversie apparatuur zijn geschied) en stelt tevens vast of de combinatie rekeningnummer-controlegetal correct is. Eerst dan wordt de post ter verdere verwerking geaccepteerd.

De vorenstaande procedure is speciaal ontworpen voor nota's die in hun geheel door een bedrijfsafdeling worden getypt. Voor veel voorkomende transacties wordt gebruik gemaakt van vóórgeadresseerde nota's die door een centrale adresseerafdeling zijn vóórgeadresseerd, of ter plaatse door een afdelingsfunctionaris van een afdruk van een elders aangemaakt plastic plaatje worden voorzien.

Wanneer, zoals hiervoor beschreven, geboekt wordt vanaf een doorslag van een originele nota, moet er voor worden gezorgd, dat de originelen van de gemaakte nota's hun bestemming, d.w.z. veelal de rekeninghouder, inderdaad bereiken. Zodra de nota door de bedrijfsafdeling is gecontroleerd, wordt het origineel aan de verzendafdeling gegeven. Het is de verzendafdeling niet toegestaan een nota terug te geven anders dan op schriftelijk verzoek van de chef van de afdeling die de nota heeft gemaakt.

Het systeem van controlegetallen, zoëven geschetst, verschaft een bijna afdoende zekerheid dat door de afdelingen met de schrijfmachine geadresseerde nota's op de juiste rekening worden geboekt. Een bezwaar tegen de hantering van controlegetallen is de extra handeling die moet worden uitgevoerd, die bovendien met zich mee brengt dat $\mathrm{bij}_{\mathrm{j}}$ abusievelijke toekenning van een verkeerd controlegetal een ,,uitvaller" ontstaat bij de computerinleesgang.

\section{Centrale initiëring van mutaties}

Tot dusverre is er steeds gesproken over boekingen die ontstaan op grond van de transacties die in het kader van de dagelijkse bedrijfsvoering ten uitvoer worden gelegd. Het zijn de bedrijfsafdelingen die de opdrachten uitvoeren en die het boekingsmateriaal gereed maken en ter conversie aanbieden. Duidelijk onderkenbaar is echter een tweede stroom opdrachten die naar het rekening-courantsysteem vloeit, en wel de machinaal leesbare boekingsopdrachten die voortkomen uit computerbestanden waarin gegevens worden bewaard die periodiek tot boekingsposten aanleiding geven.

In de eerste plaats gaat het om bestanden waarin gegevens met betrekking tot de intrestberekening worden bewaard. Elke mutatie op een rekening wordt opgeslagen tot aan het einde van de voor die rekening overeengeko- 
men intrestperiode. Zo snel mogelijk daarna wordt door een computerprogramma de verschuldigde respectievelijk te vorderen intrest (en eventuele provisies en kosten) berekend, hetgeen resulteert in een te boeken bedrag.

Een tweede belangrijke bron van boekingsmateriaal zal bij veel banken het effectenbewaringbestand zijn, dat boekingen aanbiedt in het bijzonder op grond van coupon- en dividendafrekeningen.

Er zal voor moeten worden zorggedragen dat, voorafgaande aan de dagafschriftenrun, vanuit de centrale bestanden overzichten worden afgedrukt waarop de individuele boekingen en de totaalbedragen zijn opgenomen, opdat degenen die voor de dagelijkse mutatieverwerking van het rekeningcourantsysteem verantwoordelijk zijn daarmede controle kunnen uitoefenen. (Het beheer van de centrale bestanden zal in andere handen zijn dan de controle op de verwerking van de dagmutaties.)

Ten aanzien van de boeking op de juiste rekening moet worden bedacht, dat de rekeningnummers afkomstig zijn uit beschermde computerbestanden, hetgeen de kans op foutieve nummers uiterst klein maakt.

De twee genoemde voorbeelden hebben betrekking op gegevens afkomstig uit bestanden die het karakter van bewaarbestanden hebben. In het volgende deel van dit artikel zal de nadruk meer liggen op gegevens in de transactiesfeer.

\section{De interne controle bij externe en decentrale vastlegging}

Welke ontwikkelingen zijn zichtbaar?

Er zijn op dit moment twee ontwikkelingen waar te nemen die hoewel anders van karakter, beide eenzelfde effect hebben op de rekening-courantadministratie, n.l. de onherroepelijke afbouw van op conventionele wijze gemaakte boekingsstukken, die normaliter gevolgd werd door een centrale conversie naar machinaal leesbare boekingsposten. Het zijn ontwikkelingen die, uitgaande van het principe van éénmalige vastlegging, en integratie van alle conventionele handelingen tot één geautomatiseerd proces, zich manifesteren in:

1 Op het gebied van het betalingsverkeer, zowel nationaal als internationaal: de oprichting van centra die, uitgerust met indrukwekkende electronische apparatuur, de afwikkeling van het betalingsverkeer van de individuele banken overnemen, hetzij door centrale uitvoering (nationaal) hetzij door er voor te zorgen dat de gegevens langs de weg van datatransmissie de instellingen bereiken waar de begunstigden rekening houden (internationaal). Het boekingsmateriaal kan zonder verdere menselijke tussenkomst worden afgeleid uit de machinaal leesbare gegevens die de uitvoerende instanties aan de deelnemende banken verstrekken.

2 Bij de banken intern: de bouw van op terminals gebaseerde systemen, die beogen na vastlegging van de basisgegevens van een transactie de verdere behandeling geheel machinaal te doen verlopen. In dit geintegreerde informatieverwerkingsproces wordt steeds plaats ingeruimd voor de oplevering van boekingsmateriaal, uiteraard in machinaal leesbare vorm.

Welke betekenis heeft dit alles nu voor de interne controle? In de eerste 
plaats zal de controle op de invoervastlegging zich wijzigen, omdat de boekingsgegevens op meerdere punten tot stand komen.

Maatregelen van interne controle zullen, als het goed is, mee moeten verschuiven naar de bron, om direct bij de initiëring van een boeking de nodige controles te kunnen uitoefenen.

Daarmede zal niet in alle gevallen volstaan kunnen worden. Een controlepunt dat dan ook benut kan worden is het moment waarop de elders opgebouwde boekingsposten het rekening-courantsysteem binnen komen. In de tweede plaats zal de interne controle moeten worden afgestemd op de nieuwe apparatuur die bij de vastleggingsprocedure wordt ingeschakeld.

\section{Externe aanmaak van boekingsmateriaal}

\section{- Binnenlands betalingsverkeer}

In het voorgaande is melding gemaakt van de oprichting in 1967 van de Bankgirocentrale (BGC) welk instituut primair de opdracht heeft als intermediair op te treden bij de uitvoering van door banken ontvangen binnenlandse betalingsopdrachten. De BGC verwerkte in het begin van haar bestaan uitsluitend opdrachten die werden aangeleverd in de vorm van, door banken of bankcliënten aangemaakte, ponskaarten en magneetbanden. Sedert enkele jaren worden ook opdrachten uitgevoerd die gesteld zijn op optisch leesbare formulieren, terwijl onlangs een proefperiode afgesloten is waarin handgeschreven giro opdrachten met behulp van key-to-disk apparatuur werden verwerkt. De BGC is eveneens opgedragen de landelijke clearing en verwerking (sortering) van de optisch leesbare betaalcheques. Ultimo 1972 werd ongeveer $20 \%$ van het totale door bankcliënten geinitieerde girale betalingsverkeer centraal behandeld door de BGC. Vóór $1980 \mathrm{zal}$ haar aandeel in de afwikkeling van het bancaire betalingsverkeer naar verwachting zijn opgelopen tot boven $90 \%$.

Wat is nu het verband tussen deze ontwikkeling en de rekening-courantadministratie? Wel, dat de BGC na uitvoering van de giro opdrachten aan de betrokken banken (zowel die van opdrachtgever als die van begunstigde) een verslaglegging van het proces verleent in de vorm van ponskaarten of magneetband, waarin/waarop alle gegevens omtrent de betalingen zijn opgenomen.

Deze informatiedragers vormen de input voor de dagafschriftenprogrammatuur. Dit is voor de rekening-courantverwerking een bijzonder belangrijke ontwikkeling, aangezien uit het binnenlandse betalingsverkeer veelal zeer veel boekingsposten komen.

Duidelijk is dat een gedeelte van de maatregelen van interne controle, namens de banken die deelnemen aan de BGC, wordt uitgevoerd door de BGC. Het gaat daarbij hoofdzakelijk om controle op het gebruik van juiste rekeningnummers, d.w.z. nummers die voldoen aan de 11 -proef. De positieen handtekeningfiattering ligt bij de banken waar de opdrachtgevers rekening houden, de BGC gaat niet eerder tot verwerking over dan na ontvangst van fiat van de opdrachtgevende bank. Regel is dat de BGC, voorafgaande aan de dagelijkse clearing van de verschuldigde en te vorderen gelden (via De Neder- 
landsche Bank) aan de banken het totaalbedrag meldt van de voor hun rekening uit te voeren opdrachten. De banken kunnen deze melding van de BGC vergelijken met de eerder door hen zelf ingezonden opgaven.

Zekerheid dat de BGC na afloop van haar verwerkingsgang inderdaad een juiste melding aan de aangesloten banken verstrekt, kan worden bereikt door op speciale tussenrekeningen handmatig ,soll" posities te creëren, die vanuit de door de BGC beschikbaar gestelde boekingsponskaarten of -tape worden tegengeboekt. De tussenrekeningen moeten daarna een nulsaldo aangeven.

Een belangrijk nieuw controlemiddel of op de juiste rekeningen wordt gedebiteerd en gecrediteerd, wordt gevormd door de omstandigheid dat bij de BGC verwerking een nummer-naam-bestand wordt geraadpleegd.

Het nummer-naam-bestand bevat de namen en rekeningnummers van alle bankrekeningen die met het oog op de deelname aan het betalingsverkeer bij de Nederlandse banken worden aangehouden. Wanneer een bankrekeningnummer de 11 proef is gepasseerd, wordt uit het nummer-naam-bestand de bijbehorende naam opgehaald, die op de door de BGC of door de banken vervaardigde nota's, zowel aan de debet- als aan de creditzijde, wordt afgedrukt.

Dat betekent dat de twee partijen na uitvoering kunnen vaststellen of de opdracht goed is uitgevoerd, respectievelijk van wie het bedrag afkomstig is. Met name wordt hiermede aan de opdrach tgever meer zekerheid verschaft dat de betaling inderdaad de begunstigde heeft bereikt. Bij de conventionele methode ontvangt hij weliswaar een door zijn bank gewaarmerkte copie van zijn opdracht retour, maar dat is nog geen bewijs dat de juiste begunstigde gecrediteerd is, doch slechts een mededeling dat de opdracht uitgevoerd is. De terugmelding van de naam van de wederpartij uit een computerbestand, dat door de banken zelf wordt bijgehouden, verschaft aan de opdrachtgever in tegenstelling tot voorheen wèl informatie waar de creditering terechtgekomen is.

\section{- Buitenlands betalingsverkeer}

Een groot aantal banken in West-Europa en de Verenigde Staten van Amerika is gezamenlijk bezig met de opbouw van een datatransmissienetwerk, waarlangs de internationale betalingsopdrachten kunnen worden uitgewisseld.

Het project, dat de toepasselijke naam SWIFT meegekregen heeft, wordt geacht over enkele jaren operationeel te zijn.

In tegenstelling tot de gang van zaken bij de BGC en vergelijkbare nationale instellingen in andere Europese landen, is bij het SWIFT project niet zozeer sprake van een of ander centraal verwerkingsinstituut, maar beperkt de samenwerking zich tot technische voorzieningen die het contact tussen bank van opdrachtgever en bank van begunstigde via datatransmissielijnen mogelijk maken.

Wanneer er van wordt uitgegaan, dat de bij een bank binnenkomende berichten mede de basis vormen voor het boekingsproces, bij voorkeur zonder menselijke tussenkomst, dan stelt dit de interne controlefunctionarissen opnieuw voor de vraag op welke wijze zekerheid kan worden verkregen 
dat het juiste bedrag op de juiste rekening wordt gecrediteerd. Ten aanzien van de bedragen zal de techniek waarschijnlijk wel voor een adequate oplossing kunnen zorgen. Het is n.l. aannemelijk dat een procedure zal worden ontworpen, waarbij een gedeelte van de berichten van batchtotalen zal zijn voorzien.

Moeilijker ligt het met de vraag of de juiste rekening wordt gecrediteerd. Denkbaar maar niet waarschijnlijk is, dat de ontvangende bank de naam van de begunstigde terugmeldt aan de opdrachtgevende bank, opdat evenals dit bij het binnenlands betalingsverkeer het geval is, een volledige terugkoppeling plaatsvindt. Meer ligt voor de hand, dat de ontvangende bank op grond van de naam in het bericht (na het bericht op papier te hebben afgedrukt) het te boeken rekeningnummer handmatig bijzoekt, of indien in het bericht ook een rekeningnummer opgenomen is, visueel laat nagaan of de naam in het bericht overeenstem $t$ met de naam uit het eigen rekeningenbestand. Daarbij wordt verondersteld, dat de begunstigde rekeninghouder is bij de ontvangende bank. Het zal evenwel ook voorkomen dat de begunstigde geen bankrekeninghouder is of een cliënt is bij een andere bank. In deze gevallen wordt de begunstigde geadviseerd dat er voor hem een bedrag is ontvangen met het verzoek om nadere instructies respectievelijk wordt het bedrag doorvergoed aan een andere bank. Met name de eerste vorm, t.w. advisering, moet met bijzondere zorg worden omringd, omdat het bedrag niet onmiddellijk vergoed wordt, maar op een tussenrekening geparkeerd wordt.

\section{- Interne geintegreerde aanmaak van boekingsmateriaal}

De nieuwe toepassingen zoals die in deze tijd bij de banken worden gerealiseerd of aan de realisering waarvan wordt gewerkt hebben de volgende kenmerken gemeen:

$1 \mathrm{Zij}$ hebben voornamelijk betrekking op transacties, dit in tegenstelling tot de gegevens die betrekking hebben op bewaring in ruime zin van het woord, waarmede b.v. de intrestboekingen en de boekingen uit hoofde van coupon- en dividendafrekeningen werden gekarak teriseerd.

$2 \mathrm{Zij}$ gaan duidelijk uit van een éénmalig vastleggen van basisgegevens, die de bron vormen voor de verdere verwerking naar meerdere gezich tspunten (geintegreerde gegevensverwerking), waaronder steeds de oplevering van mutaties voor de rekening-courantadministratie.

$3 \mathrm{Zij}$ zijn gebaseerd op decentrale vastlegging, althans voorzover dat uit kostenoverwegingen verantwoord is. Er wordt moderne apparatuur ingeschakeld, zoals key-to-tape/disk machines, video display units en hard copy dialoog terminals.

$4 \mathrm{Zij}$ zijn in toenemende mate ingericht voor datatransmissie van en naar centraal of regionaal opgestelde computers.

$5 \mathrm{Zij}$ maken gebruik van centrale direct toegankelijke referentiebestanden, waarmede op conversatiebasis wordt gewerkt.

$6 \mathrm{Zij}$ trachten zoveel mogelijk functies door de computer te doen verrichten, zoals rekenkundige bewerkingen en waarschijnlijkheidscontroles. 
Welke maatregelen van interne controle moeten tot stand komen?

Hiervóór werd betoogd dat de interne controle verlegd zou moeten worden naar de plaats waar de primaire registratie geschiedt. Daarbij zijn twee zaken van belang, t.w.:

1 Het gebruik van de invoerstations moet aan een strenge autorisatieprocedure worden onderworpen opdat ongeoorloofd gebruik uitgesloten blijft. In beginsel staan daarvoor twee wegen open:

a. Een autorisatieprocedure in technische zin, waarbij de eindstations beschermd worden met behulp van sleutels (zoals ook bij kassa's in warenhuizen veel wordt toegepast) of speciale schablonen die passen op een gedeelte van het toetsenbord en daarmede een bepaald gebruik mogelijk maken. Ook aan terminals gekoppelde magnetische badgelezers komen steeds meer in zwang. Uitgangspunt hierbij is dus dat in de een of andere vorm hulpmiddelen worden verstrekt, die door de operator (operatrice) moeten worden bewaard. Op deze bewaring zal stelselmatig controle moeten worden uitgeoefend om te verzekeren dat de protection keys niet in verkeerde handen komen.

$b$. Een autorisatieprocedure, waarbij een functionaris als systeembeheerder (system supervisor) de invoerstations op verzoek van de afdelingschefs toewijst aan bepaalde personen voor een bepaalde tijd en desgewenst alleen voor bepaalde intoetswerkzaamheden (b.v. alleen transacties van soort A). De toewijzing van de terminals wordt dan geregistreerd door een computerprogramma, dat aan de systeembeheerder signaleert wanneer men zich niet aan de criteria houdt en ongeautoriseerd gebruik simpelweg blokkeert. De systeembeheerder beschikt in dit geval over een zogenaamde masterterminal, waarmede hij de dagelijkse operaties bestuurt.

2 Verzekerd moet worden dat de éénmalige vastlegging resulteert in een boeking op de juiste rekening. In wezen moet nu in één keer worden gecontroleerd, wat bij de single run-oude stijl in twee étappen werd nagegaan, n.l. de controle op de juistheid van de met de schrijfmachine vervaardigde nota's en de controle op de juistheid en volledigheid van de inputvastlegging. Controle door functiescheiding kan bij een aantal applicaties zeer wel een goede oplossing zijn, zeker in die gevallen waarbij veel informatie moet worden ingevoerd. Na de vastlegging door de terminaloperator/-trice gaat het basisdocument, voorzien van een bij de computer bekend volgnummer, naar een andere functionaris, die de gegevens uit het ,,berichten" bestand terugroept op een daarvoor geautoriseerde terminal en na accoordbevinding het bericht aanvult met zijn fiatkenmerk. De computerprogramma's halen uiteraard alleen die berichten ter verdere verwerking op die zo'n fiatkenmerk dragen. Duidelijk is dat ook hier programmatische controles een ruime toepassing zullen vinden. Wanneer in dialoogverkeer wordt gewerkt, kan de juistheid van de boeking door een nieuwe controlemaatregel worden versterkt. Na intoetsing van b.v. een rekeningnummer of een ander indicatief van een rekeninghouder, zal het computerprogramma in het centraal aanwezige nummer-naambestand van de rekeninghouders de zogenaamde NAW-gegevens bijzoeken 
en die terugmelden aan de terminal. Ogenblikkelijk kan dan langs visuele weg worden vastgesteld of de juiste rekening is bereikt. Aannemende dat de programmatuur voor de verdere behandeling van de transactie in orde is, mag dan worden gesteld dat er zekerheid is dat alle bescheiden met de juiste adressering zullen worden vervaardigd en dat ook de financiële afwikkeling correct zal zijn.

\section{De dagelijkse mutatieruns}

Uitgaande van geautoriseerde inputgegevens en uitputtend uitgeteste programmatuur, is de enige die nog in het boekingsproces kan ingrijpen de computeroperator. Deze stelling gaat alleen op indien er in het rekencentrum wordt gewerkt in de ,closed shop" situatie, waarbij onbevoegden de toegang tot de computerruimte is ontzegd respectievelijk onmogelijk is gemaakt, doordat de ingang is beveiligd b.v. door een badge entry system.

De kans dat operators onrechtmatige ingrepen in de verwerkingscyclus kunnen doen is klein. Het ingrijpen veronderstelt grondige kennis van de werking van de programma's. Bovendien wordt op de console sheet van de computer een mededeling afgedrukt zodra zich een operator-interruptie heeft voorgedaan.

Tussenvoegen van eigenhandig aangemaakte mutaties zal in beginsel niet onopgemerkt behoeven te blijven, omdat de controlefunctionaris verantwoordelijk voor de rekening-courantverwerking voor zichzelf vastgesteld zal hebben voor welk bedrag er in totaal aan mutaties mag worden geboekt. Een beveiliging zal eveneens ingebouwd moeten worden tegen het onbevoegd draaien van een extra run, waarin b.v. alleen op- en afboekingen op een rekening plaatsvinden terwille van de intrestberekening, waardoor de saldi niet veranderen. Deze voorziening is simpel aan te brengen door vóór en na elke dagafschriftenrun de computer een mengelmoestotaal te laten afdrukken, bij de berekening waarvan verschillende informatie-elementen een rol spelen.

Deze hash totals van de verschillende runs moeten op elkaar aansluiten, hetgeen dagelijks gecontroleerd moet worden. Deze voorziening is evenzeer van belang om te verzekeren dat de mutatieverwerking wordt verricht op basis van het juiste oud-saldo-bestand. Een aanvullende zekerheid hierop wordt verkregen wanneer tape- en schijfbeheer in handen is van een bibliothecaris. Natuurlijk zal bij de start van de dagafschriftenrun door het computerprogramma, op basis van besturingsinformatie (met name verwerkingsdatum) gereed gemaakt door een bij voorkeur apart staande afdeling werkvoorbereiding, moeten worden nagegaan of de meest recente saldi als uitgangspunt worden genomen.

\section{Samenvatting}

In dit artikel is onderwerp van onderzoek geweest op welke wijze maatregelen van interne controle gestalte hebben gekregen bij de rekening-courantverwerking van algemene banken. Het onderzoek is begonnen met de bespreking van een systeem, dat juist uit overwegingen van interne controle ingang 
heeft gevonden, n.l. de paralleladministratie. De opvolger van de paralleladministratie t.w. de single run methode, zal niet lang in haar oorspronkelijke opzet functioneren. Het voortdurende streven naar verhoging van de efficiency bij een toenemende werklast vond in korte tijd aansluiting bij de snelle ontwikkeling van electronische apparatuur, die naar verwachting vooral in de vorm van on-line terminals duidelijk haar stempel zal drukken op de administratieve organisatie in de komende jaren. Voor de rekening-courantverwerking zal dit betekenen een drastische omwenteling van centrale conversie van boekingsgegevens naar decentrale vastlegging van basisgegevens ten behoeve van geïntegreerde informatieverwerking.

$\mathrm{Bij}$ de nieuwe toepassingen zal het accent van de interne controle moeten worden verlegd naar de werkzaamheden rondom de éénmalige vastlegging van basisgegevens. Belangrijk daarbij is de autorisatie van het terminalgebruik, de controle op juistheid en volledigheid van de ingevoerde gegevens (screening), en de controle op de successieve verwerking van de gegevens door veelal centraal opgestelde computerapparatuur. Functionarissen van de interne controle afdeling zullen zich grondige kennis van automatiseringsaangelegenheden moeten verwerven, opdat ook bij toekomstige complexe applicaties afdoende maatregelen van interne controle tot stand kunnen komen, niet in de laatste plaats gebruikmakend van de controlemogelijkheden van de computer zelf. 


\section{Geraadpleegde literatuur}

Titel

A. Boeken

1 Automatisering van de informatieverzorging

2 Auditing \& EDP

3 Leer van de administratieve organisatie, deel 1 en 2

4 Administratieve techniek, deel 1 en 2

5 Banken, hare boekhouding en organisatie, deel 1 en 2

Auteur/uitgegeven door

Jaar

$\mathrm{J}$. W. van Belkum en

A. J. van 't Klooster 1971

Gordon B. Davis 1968

R. W. Starreveld

1970

R. W. Starreveld 1964

M. C. Wintersteyn 1928

B. Brochures en tijdschriftartikelen

6 Bestuurlijke informatieverzorging bij banken

7 Automatisering en het zelfstandig oordeel van de accountant

8 De invloed van de automatisering van de informatieverwerking op de organisatie

9 Let's give the internal auditor full responsibility

10 Interne controle en beveiliging van geautomatiseerde informatiesystemen

11 De aanpassing van de organisatie van de administratie aan moderne computertechnieken

12 Automatisering en controle

13 Controle aspecten en administratieve automatisering

14 Schriftelijke cursus voor de opleiding van beambten in het bank-en effectenbedrijf

15 Mens-machine-dialoog bij de Algemene Bank Nederland

16 De GAMMA compact 10 in dienst van het bankwezen

17 Studiereis naar banken in de V.S.

18 Wisselarbitrage op de computer

19 Nieuw Amro computercentrum, basis voor communicatienetwerk

20 Amro assurantiën legt polistransacties vast met beeldstations

21 NMB-teleprocessingnet werkt met systeem 370 , model 155

22 Voorlichtingsbrochure

23 Key-punch crooks

24 De accountant en de automatisering van de administratie

J. A. de Boer

juni 1971

Maandblad voor bedrijfsadmini- jan. 1972

stratie en organisatie

L. A. van Hulsentop

juli 1972

mei 1973

1970

A. J. van 't Klooster nov./dec.

$\mathrm{MAB}$

1968

Alan Taylor, Computerworld

dec. 1972

L. C. van Zutphen

mei 1973

J. D. de Winter

juli 1971

De Accountant

NIVRA geschrift no. 1

1970

Rapport van Raadgevend Bureau 1972

Berenschot-Diebold N.V.

Nederlands Instituut voor het

1972

Bank-en Effectenbedrijf

Brochure van Honeywell Bull

Brochure van Honeywell Bull

1968

Rapport Contactgroep Opvoering

1954

Productiviteit

De Ankertros, personeelsorgaan van maart 1971

de Algemene Bank Nederland

De automatiserings-gids

28 dec.

1972

IBM kwartaalschrift jan. 1972

IBM kwartaalschrift jan. 1972

Postcheque- en Girodienst sept. 1971

Time

$25 \mathrm{dec}$.

1972

R. W. Starreveld

1967

Stramien 